ISBN 978-93-84468-75-0

2016 International Conference on Business, Human Resources and Education

(ICBHRE-16)

Oct.11-12, 2016 at Dubai (UAE)

\title{
Making Saudization Succeed: The 2020 Vision
}

\author{
Dr. Tarik Al Sulimani \\ Chief Human Capital Officer, Al Jomaih Automotive Company \\ Tarik.AlSulimani@aljomaihauto.com
}

\begin{abstract}
Saudi Arabia is known to be a rich nation in its natural resources that makes its economy among the top of other nations being a member of the top developed countries in the world. Its real wealth is solely the dependency on its people who stood strong to support the Government in all its initiatives. However, a key issue has been one of the most important issues been focused on by the Government which is manpower where almost one-third of its population are expatriates comprising mainly of imported labor to meet the requirement of the development in the country. It's quite unusual and challenging for a country to have that huge number of expats while the unemployment rate needs to be decreased to reach the projected level in a country with a high percentage of young population. In fact over $60 \%$ of the Saudi population is under the age of 20. The Government of Saudi Arabia has been trying its level best with different endeavors to increase nationalization of jobs for quite many years now, but still with limited success due to low level of achievements in some sectors from the private sector in this area.

This paper will shed light on the reasons for the underachievement of nationalization in the private sector and what are the key measures that organizations can take home to implement Saudization successfully and improve the level of employment in the private sector. The paper will also address the issue pertaining to the link between the educational system and its alignment with the labor market since the private sector is still suffering from hiring Saudi graduates from local institutes and colleges, which were not fully equipped to provide them with the needed skills to meet market and economic demands
\end{abstract}

Keywords: Saudization, Ministry of Labor and Social Development)

\section{Saudization: The Real Challenge in Saudi Arabia}

The Kingdom of Saudi Arabia is a young country by nature and have achieved the impossible in recent times to be where it is today. It is a country where two-thirds of the nation's population of 29 million or so are under the age of 30 and statistics have indicated that $37 \%$ of all Saudis are 14 years of age or even younger. In fact it is for real quite a dilemma, where over 9 million expatriates in the country dominate most of the private sector organizations at all levels from a technician or a basic laborer level all the way to the top of the pyramid, yet there is still unemployment challenges.

The Ministry of Labor and Social Development for many years has taken the lead to improve the situation by attempting to nationalize most of the positions. The term (Saudization) is a term used as a national movement to employ Saudis in place of non-Saudis and foreigners. The Government has taken the responsibility to improve employment participation of Saudi nationals in the private sector. Issues such as unemployment of youth and measures have been taken to reduce the domination of expatriate workforce are of real concern in the country today. The education system in the country may not has reached the level required in the past years which could have satisfied the needs and requirements of the businesses and companies. Some of the primary and secondary school students' are not getting the level of education needed to make a difference in their skills. This has left a large gap where by many of the students who complete studies to reach college level have failed 
to acquire the level of education and skills required for the needed jobs that are filled with expats with some exceptions. Basically students who pass out of school and colleges do not have the dynamics and the needed flexible skills that employers are looking for. In addition, many students have degrees that are not useful for private-sector jobs and that would allow private-sector companies to rely more on non-Saudi workers to fill this gap. Such issues have created a large room for the unemployment of youth and unfocused efforts on the improvement of Saudization to be where it is today and is still one of the biggest challenges facing the Government.

It is worth mentioning here that the country hasn't spared any effort to resolve the unemployment issue and has given full support to companies to increase the level of Saudization in them. In fact, in 2015 alone Saudi budget in education was increased by 3 percent where roughly ( $\$ 58$ billion) has been allocated towards education, and about (\$108) million on general school rehabilitation projects, and over (\$3) billion towards higher education.

During late King Abdullah's time, he tried to modernize the education system in the country through many significant initiatives. This included the creation of King Abdullah University for Science and Technology in 2009, a state-of the art university with a cost around (\$10) billion. In addition, late King Abdullah launched in 2007 one of the largest initiatives to improve the level of education in the Kingdom through "The King Abdullah Project for the Development of Public Education" in order to improve the education system in general with a cost around (\$3) billion which included the improvement of the extracurricular activities, train teachers, develop curriculum, and much more. During his time also, he initiated King Abdullah scholarship program abroad where over 100,000 Saudi students both male and female have been in international universities at one point of time through fully paid scholarships to have the best education from the top universities in the world. On top of that, the Government has created what is called "The Human Resources Development Fund (HRDF)" program where they support private-sector organizations in salary payments, training and development, and others again to support the creation of jobs for Saudis and improve the level of Saudization across the board.[2].

Today, the Government of Saudi Arabia is continuing with greater efforts to focus on education at all levels in order to generate the needed skilful Saudis that can contribute to the development of the country and with less reliance on expatriate workforce. However, with all these exceptional initiatives and country's heavy focus and spending, the private sector in particular is struggling to move the Saudization level beyond the $30 \%$ or so as an average. This has forced the Government through the Ministry of labor and Social Development to take extra measures with more emphasis on Saudization through the enforcement of various key regulations on privatesector companies.

\section{Saudization Policy in Saudi Arabia:}

The Government through its five-year development plans since the 1970s has included noticeable priorities in the employment of the national workforce. However, it was not until the sixth five-year national development plan in the 1990s where much more serious focus was given to set greater emphasis towards Saudization and enforce it on companies. As indicated above, the Ministry of Labor and Social Development has in the past five years taken greater measures and steps to enforce Saudization.

Among those was the main scheme called "Nitaqat" which is basically a range that private-sector companies need to maintain a certain level of percentage of Saudi nationals in each organization. In basic terms, it classify Saudi companies into five categories according to the number of their workforce and it calls for an increase in the share of national manpower to total employment and for expanding work opportunities for both Saudi male and female youth. The Nitaqat scheme was launched in June 2011 to enhance the effectiveness of Saudization policy. The great feature of this program is that it is basically a rewarding system that will compensate those organizations that maintain certain levels of Saudi workforce and entitle them with various benefits. Those organizations in the green and platinum category will be eligible to get very prestigious benefits including the hiring from any nationality from anywhere in the world, apply for new visas for foreign workers with open 
profession, and much more. Organizations in the yellow and red categories are given a period of nine months for yellow and six months for red to improve their status by hiring more locals before the deadline for imposing penalties resumes.

TABLE I: The Saudization percentage and Nitaqat for Wholesale and Retail Sector

\begin{tabular}{|l|c|c|c|c|}
\hline \multirow{2}{*}{ Total No. of Employees } & \multicolumn{4}{|c|}{ Saudization Percentage } \\
\cline { 2 - 5 } & Red & \multicolumn{4}{|c|}{ Yellow } & Green & Platinum \\
\hline 1 1-9 employees & \multicolumn{4}{|c|}{} \\
\hline $10-49$ employees & $0-4 \%$ & $5-9 \%$ & $10-39 \%$ & $>40 \%$ \\
\hline $50-499$ employees & $0-5 \%$ & $6-11 \%$ & $12-39 \%$ & $>40 \%$ \\
\hline $500-2,999$ employees & $0-6 \%$ & $7-11 \%$ & $12-39 \%$ & $>40 \%$ \\
\hline More than 3,000 employees & $0-6 \%$ & $7-11 \%$ & $12-39 \%$ & $>40 \%$ \\
\hline
\end{tabular}

Another scheme that was recently introduced by the Ministry of labor was a scheme called "Mawzoon" or Balanced Nitaqat[3], which is designed to provide quality employment to Saudi nationals in the private sector. Balanced Nitaqat is due to be introduced by December 2016. Under the new system there will be five criteria according to which an employer's compliance rating will be decided upon;

1. The number of Saudi nationals employed in the business;

2. The average salary paid to Saudi employees in the business;

3. The number or percentage of Saudi women employed in the business;

4. Retention of Saudi nationals within the business; and

5. The number or percentage of Saudi nationals within the top $25 \%$ of highly paid employees.

Under the revised system, points will be awarded as follows:

- 10 points for every $1 \%$ of Saudization achieved:

- 6 points for every 1000 SR in the average salary for Saudi nationals;

- 1 point for every $1 \%$ of the workforce represented by Saudi female employees;

- 4 points for the average each year retention period of Saudi nationals; and

- Points for the percentage of Saudi nationals within the top 25\% of highly paid employees [3].

\section{Implementation Plan of Saudization:}

\subsection{Involve Top Management:}

In order for any plan to succeed, it is very important that key people should be involved in implementing the process and this includes the top management too. In all cases the person in charge of implementing the plan of Saudization should be able to get all the support and cooperation from the departments and functions involved in this process. However, in some cases such plans when they reach the top, they may end up in failure. Therefore, its essential that as soon as the plan is ready and completed that it gets presented to top management for them to be aware of all the implications of the plan including, financial implications, Legal if any, moral implications due to the services of the non-Saudi staff being terminated because of Saudization, etc. Once approval is granted from top management, then the plan must be presented to key stakeholders and related functions for their support as well. This could be the most difficult issue in the entire implementation of the Saudization plan as it is common knowledge that people are resistant to change. Here the change involves an upheaval in the daily routine and includes training and supervision. Moreover, in the initial phase the organizations will witness reduced revenues and increase in spending, but this is a temporary phase and within some months, the situation will return to normal. It is to overcome this lean phase that it is important to involve top management and secure their support and approval.[4]. 


\subsection{Ensure Success of the Plan:}

Departments that are part of the execution of the plan will sometimes be shown resistance towards Saudization since there is always a belief that Saudization will have an impact on the operations and the business. It is important to make the concerned management understand that this is not the case and Saudization can be made highly successful by placing the right person in the right job. Saudi workers like all other workers need to be trained in the proper skills and it is the responsibility of all to ensure that every local hired is given proper training in the required skills. The Government is very keen to support in training Saudi nationals and for this purpose has set up the Human Resources Development Fund (HRDF). HRDF has various training programs to suit the requirements of the organizations. Moreover, HRDF funds the training and for a certain period funds part of the salaries of Saudi nationals. This indicates the length to which the Government goes to make the transition smooth and less burdening on the organization both in terms of financial to the organization and imparting skills to the nationals. The organization should take advantage of the resources offered by the Government in making Saudization successful.

\subsection{Develop a Training Plan:}

Since we have indicated that resistance to change will be strong from some functions, it is essential that the department in charge of Saudization which is HR, put more emphasis on developing a training plan to prepare the newly hired Saudis who have been hired to take over the jobs of non-Saudis. Sometimes, companies find it very difficult to find the Saudi candidates with the required skills and experience ready to start on the job immediately. Therefore, HR needs to have a plan ready to excel the level of performance and competencies of the newly hired Saudis. It becomes very important for the HR department to prepare a training plan for the newly hired employees and put it into action so that these newly hired national employees are familiar with their job requirements prior to releasing the non-Saudi workers. The Government as outlined earlier provides all the required support and facilities to ensure that the companies induct skilled employees in the organization.

\subsection{Provision of Lead Time for the Change:}

Unfortunately, many organizations fail to implement Saudization effectively since they implement Saudization without proper planning. It is very essential to allow enough and ample time for the execution of the plan so that the impact on the operation will be minimum during the change process. Normally it takes time for any new employee to come to a point where his productivity reaches its optimum level and there is also the learning curve which indicates that the employee may take a few days or weeks to reach his optimum potential and become productive for the organization. Therefore, it will be a good practice to become proactive and take necessary measures to keep adequate lead time for the process to be successful.

\subsection{Allow Saudization to Happened Naturally:}

Many Saudization initiatives have failed because its implementation was mainly focused on replacement of non-Saudis with Saudis. It is no doubt that at the end it's a fact that non-Saudi staff will ultimately have to be replaced. However, it is important to keep in mind that if non-Saudi staff are told that their positions will be Saudized, then they will be demotivated, will not train Saudi staff, and will have a major impact on the success of the organization as a whole. Therefore, it would be a much better plan if Saudization is done gradually and naturally through growth. To achieve this plan the organization will have to hire a fraction of additional Saudi workers in the organization and let them get familiar with the tasks while making plans to phase out non-Saudis through natural attrition.

\subsection{Share Success Stories with Management:}

There are a number of organizations in the Kingdom and in various regions that have become models of success in employing high percentage of Saudis even in highly specialized jobs. There are many reasons for their success and one of them is they have started implementing Saudization from the beginning or from a long time. These organizations were to some extent were proactive and also cared for the interest of the nation and its 
peoples. These organizations not only employed a large percentage of Saudi nationals but also set up training institutes to train these employees as well as others willing to learn and made them ready to handle responsibilities. The other factor responsible for their success is the support and active participation of the senior and top management in the organization. Finally these organizations have done the Saudization as a gradual and natural process. They have included serious initiatives and training plans to develop the needed Saudis for their jobs and they have put them in the proper On Job Training for them to excel. The HR department has to create role models in the organization and should spread this information to all departments. Such instances will be prime examples that Saudization is not only possible but Saudis can excel in their performance and could be as good as the non-Saudis and in many cases better than them.

\section{Conclusion:}

The Kingdom of Saudi Arabia has recently approved plans for a major economic revamp and new methodology and roadmap for economic and developmental action aimed at diversification its economy away from oil in a time where the world is witnessing a significant drop in oil process. His Royal Highness, Prince Mohammed bin Salman has been the key architect of all the key future plans in the country for the Kingdom to be to be in a leading position in all fields and in education, Saudi Arabia's Vision of both the 2020 and the 2030 sought to identify the general directions, policies, goals, and objectives of the Kingdom. Accordingly, some ministries, institutions, and government entities have undergone or will be undergoing a restructuring process in order to align them to this major restructuring in the country. Shifting from an oil-based economy country and rely on other resources to build the country is an amazing and great goal which would require a complete change in almost all aspects of the business. This would no doubt would require heavy focus and emphasis on education in general and developing world-class skilled workforce needed to drive the country to the new era. [5]

The program uses innovative methods to identify challenges, seize opportunities, adopt effective planning tools and measures, activate the role of the private sector more and make them partners in the process, bring about implementation, and evaluate performances. The Vision's governance model promotes efficient planning within Government sectors and boosts coordination among them in order to achieve common national successful goals. It also guarantees speedy completion of projects and initiatives and achieves sustainable action and impact through regular implementation reviews and performance evaluations. The Vision of 2030 which was launched under the leadership of King Salman bin Abdulaziz, Custodian of the Two Holy Mosques is an amazing vision, great and well-thought of initiative, very realistic and will set the country towards a successful future for its citizens. All success stories start with a vision that are based on strong pillars. These pillars are:[6]

- The status of Saudi Arabia being the heart of the Arab and Islamic world as it is the land of the Two Holy Mosques.

- The determination to become a global investment powerhouse with its strong investment capabilities to stimulate the economy and diversify the revenues of the country.

- Transform countries unique strategic location into a global hub connecting three continents, Asia, Europe and Africa and make it an epicenter of trade and gateway to the world.

Saudization is bound to succeed because Saudi Arabia has a large supply of manpower unlike some countries that have wealth but a small population and need to import manpower from other countries.

Saudi Arabia has the wealth and resources to augment the talent and skills of the local population. Saudi Arabia has large reserves of natural resources besides oil and could supplement the revenue of the country.

Having all these positive factors, it is only a matter of time, the determination of the Government and the compliance by the organizations to ensure that Saudis stop relying on external manpower to contribute to the development of the country. Saudi nationals should be made aware of the various opportunities available and they should be made aware of their potential and the ways and means to increase their potential. We can and we 
should have each and every Saudi productively employed and reduce unemployment to a negligible level. With the support of all, Saudization will defiantly be reached in no time

\section{References}

[1] The Nitaqat Program - Ministry of Labor by Dr. Amre Masoud, Nitaqat Program Manager November 2013.

[2] Saudi Arabia's Youth Unemployment Problem - Julia Glum Jan. 2015

[3] Saudi Gazette, June 15, 2016, Ministry of Labor and Social Development

[4] The Partnership between Total Quality Management and Human Resources by Tarik Sulimani at 30th IFTDO International Conferenced \& Exhibition, Brazil, April 2001.

[5] National Transformation Program - Saudi Vision 2030

[6] Foreword - vision2030.gov.sa 